\title{
УСПАДКОВУВАНІСТЬ ТА СПІВВІДНОСНА МІНЛИВІСТЬ 3 НАДОЄМ ЛІНІЙНИХ ОЗНАК КОРІВ-ПЕРВІСТОК ГОЛШТИНСЬКОї ПОРОДИ
}

\author{
Карпенко Богдан Миколайович \\ аспірант, спеціальність 204-ТВППТ \\ Сумський національний аграрний університет \\ ORCID: 0000-0002-9942-5863 \\ E-mail: karpenkobogdan95@gmail.com
}

Проведені дослідження з оцінки корів-первісток голштинської породи (української чорно-рябої молочної з умовною кровністю голштина вище за 93,75 \%) за екстер'єрним типом. База досліджень - племінний завод ПП “Буринське” Підліснівського відділення Сумського району. Використовували сучасну методику лінійної класифікації з оцінкою за двома системами: 9-бальною, з описуванням 18 статей екстер'єру, i 100-бальною, з урахуванням чотирьох комплексів селекційних ознак, які характеризують: молочний тип, тулуб, кінцівки і вим'я. Викладено популяиійно-генетичний аспект з визначення успадковуваності та співвідносної мінливості лінійних ознак з надоєм корів голштинської породи вітчизняної селекції в Сумському регіоні. Встановлено, що найкраще корелюють з величиною надою групові ознаки, які характеризують молочний тип корів (r=0,398), розвиток тулуба $(r=0,412)$, стан кінцівок $(r=0,215)$, морфоологічні якості вимені $(r=0,466)$ та фрінальна оцінка типу ( $r=0,474)$. Найвищі коефііцієнти успадковуваності виявлено для групових ознак молочного типу $\left(h^{2}=0,366\right)$, myлуба $\left(h^{2}=0,328\right)$, вимені $\left(h^{2}=0,385\right)$ та фінальної оцінки $\left(h^{2}=0,477\right)$. Середній та помірний рівень успадковуваності встановлено за описовими ознаками: висотою ( $\left.h^{2}=0,286\right)$, глибиною тулуба $\left(h^{2}=0,275\right)$, кутастістю $\left(h^{2}=0,414\right)$, шириною заду $\left(h^{2}=0,295\right)$, поставою тазових кінцівок $\left(h^{2}=0,274\right)$, переднім $\left(h^{2}=0,351\right)$ і заднім $\left(h^{2}=0,296\right)$ прикріпленням вимені та центральною зв'язкою ( $\left.h^{2}=0,294\right)$. Встановлений достатній рівень успадковуваності лінійних ознак та співвідносної мінливості між ними та надоєм дозволяє селекціонерам ефективно вести добір молочної худоби у напрямку поліпшення екстер'єру та продуктивності.

Ключові слова: голштинська порода, екстер'єр, надій, кореляція, успадковуваність.

DOI: https://doi.org/10.32845/bsnau.Ivst.2020.3.8

Ефективність генетичного поліпшення молочних порід та селекціонованих стад з їх розведення за господарськи корисними ознаками залежить від ряду популяційно-генетичних параметрів найважливішими із яких є успадковуваність та співвідносна мінливість. У першому варіанті, від співвідношення ступеня спадкової і паратипової мінливості в загальній фенотиповій варіабельності ознаки значною мірою буде залежати ефективність добору, спрямованого на генетичне поліпшення популяції тварин за тією чи іншою селекціонованою ознакою. Це означає, що ознаки, які мають високу ступінь успадковуваності, меншою мірою залежать від паратипових чинників, тому їх можна швидше удосконалити прямим добором, тобто добором кращих тварин за ними. Показник успадковуваності може використовуватись у якості орієнтира при плануванні племінної роботи. Із його допомогою можна прогнозувати селекційну цінність особин за фенотипом [2, 5, 20, 27].

У практичній селекції молочної худоби світу через поширене використання методики лінійної класифікації для оцінки типу корів істотно зростає важливість вивчення успадковуваності екстер'єрних статей $[10,30,38]$ Численними науковими дослідженнями доведено, що рівень коефіцієнта успадковуваності залежить від ряду генетичних чинників, таких як порода, генотип, лінійна належність тощо [21, 30, 37].

Отримані дослідниками у стадах з розведення української червоно-рябої та чорно-рябої молочних порід Черкащини та Сумщини $[22,26]$ достовірні високі та помірні коефіцієнти успадковуваності групових ( $\left.h^{2}=0,235-0,396\right)$, більшості описових $\left(h^{2}=0,208-0,384\right)$ ознак екстер'єру та фінальної оцінки типу $\left(h^{2}=0,404-0,504\right)$, голштинізованої чорно-рябої худоби Казахстана [8] за оцінкою загального виду будови тіла $\left(h^{2}=0,18-0,46\right)$, вимені $\left(h^{2}=0,21-0,51\right)$ та кінцівок $\left(h^{2}=0,12-0,37\right)$, чеських корів симентальської породи за описовими ознаками

типу $\left(h^{2}=0,30-0,59\right)$ [37], свідчать про ефективність селекції порід молочної та комбінованої худоби за типом.

Разом 3 тим, існують повідомлення про істотну мінливість коефіцієнтів успадковуваності описових лінійних ознак екстер'єру корів голштинізованої чорно-рябої породи $\left(h^{2}=0,13-0,29\right)$ [9], голштинської худоби Туреччини $\left(h^{2}=0,06\right.$ $0,62)$ [32], голштинів $\left(h^{2}=0,07-0,36\right)$ [35] та джерсеїв $\left(h^{2}=0,09\right.$ $0,55)$ [38] Бразілії, словенської бурої швіцької $\left(h^{2}=0,03-0,22\right)$ [40], бурої швіцької $\left(h^{2}=0,099-0,453\right)$ та гернзейської $\left(h^{2}=0,078-0,428\right)$ порід США [42]. Отже, наведені показники успадковуваності лінійних ознак типу корів різних порід світу свідчать, що в одних випадках успадковуваність окремих описових ознак достатньо висока, в інших помірна, іноді низька, але загалом достатня для подальшого їх поліпшення завдяки спрямованій селекції.

Добір кращих за фенотиповим проявом особин за високої успадковуваності дозволить істотно зрушити ознаку потомства у бажаному напрямку її розвитку, тоді як за низької успадковуваності ознаки відбувається майже повне ії повернення до середньої величини вихідного покоління. За певного скорочення генетичної мінливості знижується реакція на добір, отже і на реалізацію успадковуваності [18].

Важливо враховувати знання 3 того, що успадковуваність завжди проявляється в конкретних умовах середовища $[1,6]$. Генотип визначає лише норму реакції організму на зовнішні умови. Міняються умови - неминуче змінюється і норма реакції. Отже це значить, що відділяти вплив успадковуваності від впливу середовища можливо лише з великою часткою умовності і лише в обмежених границях коливання зовнішніх факторів. У зв'язку з цим виникає необхідність постійного генетико-популяційного моніторингу стад за показниками успадковуваності кількісних господарськи корисних ознак, що дозволяє істотно підвищити

Вісник Сумського національного аграрного університету Серія «Тваринництво», випуск 3 (42), 2020 
ефективність селекційного процесу за умови отримання високого ступеня коефіцієнтів $[3,17]$. Це стосується також лінійних ознак екстер'єру, оскільки між ними та господарськи корисними ознаками взагалі та, особливо, молочної продуктивності існує кореляція різного спрямування, ступеня та достовірності.

Оскільки організм тварини є єдиною самоуправляючою системою, що склалася у процесі тривалої еволюції, коли окремі частини організму, органи, тканини, ознаки знаходяться у взаємному зв'язку один з одним, вивчення зв'язків між господарськи корисними ознаками має велике значення для селекційно-племінної роботи. Особливо важливим $€$ те, що зв'язки, які існують в організмі тварини, не $€$ абсолютними, вічними, оскільки їх контролює природний або штучний добір [11]. Задля ефеективності добору за ознаками із низькою успадковуваністю облік ознак, що корелюють, має вирішальне значення. При цьому включення до селекції таких співвідносних ознак, успадковуваність яких дуже низька - єдино можливий спосіб для досягнення успіху селекції.

Поширена в усьому світі методика лінійної класифікації корів молочних порід за типом зумовлена перш за усе існуванням тісного та помірного зв'язку більшості ознак екстер'єру з молочною продуктивністю [15, 19, 22, 23, 33], тривалістю життя [24, 25, 31, 34, 39] та відтворенням [28, 36]. Тому, 3 метою підвищення ефективності селекції корів $3 \mathrm{O}=(\mathrm{MT} \cdot \mathrm{O}, 15)+(\mathrm{T} \cdot \mathrm{O}, 2 \mathrm{O})+(\mathrm{K} \cdot 0,25)$

Успадковуваність селекційних ознак визначали за показником сили впливу батька на їхній розвиток у напів-сибсів в однофракторному дисперсійному комплексі $\left(h^{2}=\eta_{\mathrm{x}}^{2}\right)$.

Дані експериментальних досліджень (кореляційний аналіз) опрацьовували біометричними методами на ПК у середовищі Microsoft Office Excel за використання програмного забезпечення за формулами, наведеними Е.К. Меркурьевой [13].

Результати досліджень. В.П. Буркат та співавтори [4] відмічаючи важливість та необхідність використання у селекційній практиці молочного скотарства оцінки та добору худоби за зовнішніми формами і пропорціями будови тіла, наголошують, що цей селекційний захід зумовлений найперше встановленим у багатьох дослідженнях зв'язком між екстер'єрно-конституціональними характеристиками тварин та їх продуктивністю. Тобто у даному випадку реалізується відповідний зв'язок між формою і функцією, екстер'єром, як детермінуючим чинником функціональної надійності організму тварин - цілісної біологічної системи та результуючою головною господарськи корисною ознакою їхньої продуктивності [7, $16]$.

За результатами досліджень, наведеними у таблиці, найкраще корелюють з величиною надою групові ознаки, які характеризують молочний тип корів-первісток ( $r=0,398$; $\mathrm{P}<0,001)$, розвиток тулуба $(r=0,412 ; \mathrm{P}<0,001)$, морфологічні якості вимені $(r=0,466 ; P<0,001)$ та з фінальною оцінкою типу $(r=0,474 ; P<0,001)$. Виявлена дещо менша кореляція між групою ознак, які характеризують стан кінцівок ( $\mathrm{r}=0,215$; $\mathrm{P}<0,001)$, проте вона також високодостовірна, що забезпечить їхнє поліпшення за результатами добору.

Не менш важливим чинником успішної селекції в популяції молочної худоби є рівень кореляційної мінливості голштинської породи українського походження на сучасному етапі, дослідження за екстер'єрним типом вбачається вмотивованим, оскільки добір тварин бажаного молочного типу дозволить удосконалювати стадо не лише за ознаками молочної продуктивності, а й за довговічністю та відтворними якостями.

Матеріали та методи досліджень. Матеріалами досліджень слугувала інфрормація з лінійної класифрікації корівпервісток племінного заводу компанії "Укрлендфармінг” ПП "Буринське" Підліснівського відділення Сумського району. Оцінювались тварини із умовною кровністю за голштинською породою вище за 93,75 \%, які, згідно з чинною інструкцією 3 бонітування великої рогатої худоби молочних і молочно-м'ясних порід, відносяться до чистопородних тварин за поліпшувальною породою [44]. Оцінка екстер'єрного типу корів-первісток проводилася за методикою лінійної класифікації [14] згідно останніх рекомендацій ICAR [12] у віці 2-4 місяців після отелення за двома системами: 9-бальною, з лінійним описом 18 статей екстер'єру і 100-бальною з урахуванням чотирьох комплексів селекційних ознак, які характеризують: вираженість молочного типу, розвиток тулуба, стан кінцівок і морфологічні якості вимені. Кожен екстер'єрний комплекс оцінювався незалежно маючи свій ваговий коефріцієнт у загальній оцінці (3О) тварини: молочний тип (МТ) - $15 \%$, тулуб (Т) $20 \%$; кінцівки $(\mathrm{K})-25 \%$ та вим'я (B) $-40 \%$.

Загальну оцінку типу визначали за формулою:

$+(\mathrm{B} \cdot \mathrm{O}, 4 \mathrm{O})$

описових ознак екстер'єру з молочною продуктивністю. За даними досліджень зв'язку між оцінками описових ознак та величиною надою спостерігаються кореляції різної сили та спрямованості. Найвищий рівень достовірного додатного зв'язку з величиною надою за першу лактацію виявлено за оцінками описових ознак, які характеризують вираженість молочного типу корів, відповідають за міцність та здоров'я тварини, функціональність та технологічність: висотою ( $r=0,387)$, глибиною тулуба $(r=0,417)$, кутастістю $(r=0,452)$, шириною заду $(r=0,378)$, поставою тазових кінцівок $(r=0,385)$, прикріпленням передніх $(r=0,432)$ та задніх $(r=0,366)$ часток вимені, центральною зв'язкою $(r=0,326)$ та переміщенням $(r=0,263)$.

Між технологічними ознаками вимені (розташуванням передніх і задніх дійок та їхньою довжиною) та величиною надою виявлена від'ємна кореляція. У випадку отримання достовірної помірної від'ємної кореляції між розташуванням передніх і задніх дійок та надоєм $є$ пояснення, яке полягає у тому, що із наповненням вимені молоком воно розширюється з одночасним збільшенням відстані між дійками знижуючи оцінку.

Що стосується від'ємної кореляції вгодованість/надій $(r=-0,361)$, то дана ситуація пояснюється головним чином існуванням негативного енергетичного балансу високопродуктивних корів у перші 100 днів лактації, це виникало якраз тоді, коли проводилася у них лінійна оцінка згідно з вимогами методики. Взагалі, з точки зору бажаного екстер'єрного типу корів молочної худоби, є об'єктивне, загальноприйняте розуміння, що корови спеціалізованих молочних порід, які відносяться до інтенсивного типу, вгодованими ніколи не бувають. Результати наших досліджень узгоджуються з аналогічними даними багатьох науковців зарубіжних країн. Так від'ємний коефріцієнт кореляції між вгодованістю та надоєм у корів голштинської породи Швейцарії становив -0,35 (фенотипової) 
та -0,45 (генотипової) [30], помісних фризськиххбунайських корів -0,370 (фенотипової) та -0,465 (генотипової) [29], голштинів Турції -0,20 (фенотипової) та -0,34 (генотипової)
[41], голштинських корів Чехії -0,15 (фенотипової) та -0,34 (генотипової) [43].

\section{Успадковуваність та співвідносна мінливість 3 надоєм лінійних ознак корів-первісток голштинської породи піддослідного господарства \\ (враховано тварин - 135, градації організованого фактору - 12)}

\begin{tabular}{|c|c|c|c|c|c|}
\hline \multicolumn{2}{|c|}{ Ознаки екстер'єру } & $r \pm m_{r}$ & $t_{r}$ & $h^{2}$ & $\mathbf{F}$ \\
\hline \multicolumn{2}{|c|}{$\begin{array}{l}\text { Групові ознаки: } \\
\text { молочного типу }\end{array}$} & $0,398 \pm 0,054^{* * *}$ & 7,37 & $0,366^{* * *}$ & 13,3 \\
\hline \multicolumn{2}{|l|}{ тулуба } & $0,412 \pm 0,049^{\star \star \star}$ & 8,41 & $0,328^{\star \star \star}$ & 10,6 \\
\hline \multicolumn{2}{|l|}{ кінцівок } & $0,215 \pm 0,059^{* * *}$ & 3,64 & $0,257^{\star \star \star}$ & 9,5 \\
\hline \multicolumn{2}{|l|}{ вимені } & $0,466 \pm 0,057^{* * *}$ & 8,18 & $0,385^{* * *}$ & 14,2 \\
\hline \multicolumn{2}{|l|}{ Фінальна оцінка } & $0,474 \pm 0,053^{* * *}$ & 8,94 & $0,477^{\star * *}$ & 18,8 \\
\hline \multicolumn{2}{|c|}{ Описові ознаки: висота } & $0,387 \pm 0,049^{* * *}$ & 9,29 & $0,286^{\star \star *}$ & 7,84 \\
\hline \multicolumn{2}{|l|}{ ширина грудей } & $0,103 \pm 0,058^{*}$ & 1,78 & $0,163^{\text {*** }}$ & 6,55 \\
\hline \multicolumn{2}{|l|}{ глибина тулуба } & $0,417 \pm 0,043^{* * *}$ & 9,70 & $0,275^{\star \star *}$ & 8,77 \\
\hline \multicolumn{2}{|l|}{ кутастість } & $0,452 \pm 0,057^{* * *}$ & 7,93 & $0,414^{* * *}$ & 16,1 \\
\hline \multicolumn{2}{|l|}{ нахил заду } & $0,085 \pm 0,059$ & 1,44 & 0,079 & 0,74 \\
\hline \multicolumn{2}{|l|}{ ширина заду } & $0,378 \pm 0,051^{* * *}$ & 7,41 & $0,295^{\star \star *}$ & 9,33 \\
\hline \multicolumn{2}{|c|}{ кут скакального суглоба } & $0,139 \pm 0,061^{*}$ & 2,28 & 0,083 & 0,68 \\
\hline \multicolumn{2}{|c|}{ постава тазових кінцівок } & $0,385 \pm 0,044^{\star \star \star}$ & 8,75 & $0,274^{\star \star *}$ & 9,22 \\
\hline \multicolumn{2}{|c|}{ кут ратиць } & $0,122 \pm 0,051$ & 2,39 & $0,165^{\star *}$ & 3,23 \\
\hline \multirow{2}{*}{ прикріплення вимені } & переднє & $0,432 \pm 0,049^{* * *}$ & 8,82 & $0,351^{* * *}$ & 9,77 \\
\hline & заднє & $0,366 \pm 0,055^{* * *}$ & 6,65 & $0,296^{* * *}$ & 7,56 \\
\hline \multicolumn{2}{|l|}{ центральна зв'язка } & $0,326 \pm 0,050^{* * *}$ & 6,52 & $0,294^{* * *}$ & 8,61 \\
\hline \multicolumn{2}{|l|}{ глибина вимені } & $0,064 \pm 0,051$ & 1,25 & $0,141^{* \star *}$ & 3,58 \\
\hline \multirow{2}{*}{ розташування дійок } & передніх & $-0,166 \pm 0,053^{\star *}$ & 3,13 & 0,052 & 1,64 \\
\hline & задніх & $-0,178 \pm 0,052^{* * *}$ & 3,42 & 0,058 & 1,67 \\
\hline \multicolumn{2}{|l|}{ довжина дійок } & $-0,066 \pm 0,051$ & 1,29 & $0,173^{\text {** }}$ & 4,82 \\
\hline \multicolumn{2}{|l|}{ переміщення (хода) } & $0,303 \pm 0,059^{\star \star \star}$ & 4,45 & $0,187^{* \star *}$ & 6,61 \\
\hline \multicolumn{2}{|l|}{ вгодованість } & $-0,361 \pm 0,061^{* * *}$ & 5,91 & $0,089^{* *}$ & 2,59 \\
\hline
\end{tabular}

Із досвіду селекційної роботи добре відомо, що біологічні властивості живих організмів та рівень розвитку селекціонованих кількісних ознак тварин контролюються дією двох груп чинників - спадкових та середовищних. Проте для практичної селекції дуже важливо відокремлено визначати ступінь впливу кожного із спадкових чинників у загальній мінливості взятих для дослідження показників. Використовуючи дисперсійний аналіз, ми одержуємо математичний вираз мінливості, обумовлену дією врахованих у досліді факторів та визначаємо статистичну достовірність частки впливу факторів, що вивчаються [17].

Визначені нами коефіцієнти успадковуваності ознак лінійної оцінки голштинських корів-первісток у стаді підконтрольного підприємства виявились до певної міри мінливими i, у більшості випадків, достовірними за критерієм Фішера.

Рівень коефіцієнтів успадковуваності виявився достатнім для ефективного добору корів за важливими для молочної худоби груповими ознаками, які характеризують молочний тип $\left(h^{2}=0,366\right)$, розвиток тулуба $\left(h^{2}=0,328\right)$, вимені $\left(h^{2}=0,385\right)$ та за фінальною оцінкою типу $\left(h^{2}=0,477\right)$. Рівень успадковуваності, який дозволяє вести ефективну селекцію встановлено й за описовими ознаками - висотою у крижах $\left(h^{2}=0,286\right)$, глибиною тулуба $\left(h^{2}=0,275\right)$, кутастістю $\left(h^{2}=0,414\right)$, шириною заду $\left(h^{2}=0,295\right)$, поставою тазових кінцівок $\left(h^{2}=0,274\right)$, переднім $\left(h^{2}=0,351\right)$ і заднім $\left(h^{2}=0,296\right)$ прикріпленням вимені та центральною зв'язкою $\left(\mathrm{h}^{2}=0,294\right)$.

Висновки. 1. Встановлена істотна та достовірна співвідносна мінливість групових та описових статей екстер'єру з надоєм за першу лактацію підтверджує настійну необхідність опосередкованої селекції молочної худоби за типом, що дозволить отримати не лише конституціонально міцних та здорових тварин, а й високопродуктивних за надоєм.

2. Встановлений ступінь мінливості коефіцієнтів успадковуваності лінійних ознак свідчать про відповідний рівень селекції корів за екстер'єрним типом, адекватно характеризуючи їхню генетичну варіативність у загальній фенотиповій різноманітності популяції за будовою тіла. Селекціонери молочної худоби мають змогу швидше досягти поставленої мети за умов цілеспрямованого добору тварин за показниками лінійної оцінки, які мають високий рівень успадковуваності.

\section{Список використаної літератури:}

1. Адушинов Д., Лазарев Н., Истомин А., Митренга В. Тип телосложения и хозяйственно-полезные признаки голштинизированного черно-пестрого скота. Молочное и мясное скотоводство. 2011. № 5, С. 16-17.

2. Басовский, Н. 3. Популяционная генетика в селекции молочного скота. М.: Колос, 1983. 256 с.

3. Буркат В. П., Єфіменко М. Я., Подоба Б. Є., Дзіцюк В. В. Наукові і прикладні аспекти генетичного моніторингу у тваринництві. Вісник аграрної науки. 2003. №5, С. 32-39.

4. Буркат В. П., Полупан Ю. П., Йовенко І. В. Лінійна оцінка корів за типом. К.: Аграрна наука, 2004. 88 с.

5. Гопка Б. М., Коваленко В. П., Мельник Ю. Ф., Коваленко В. П., Угнівенко А. М. та ін. Селекція сільськогосподарських 
тварин. За ред. Ю. Ф. Мельника, В. П. Коваленка та А. М. Угнівенка. К.: «Інтас», 2008. 445 с.

6. Делян А. Щеглов Е., Усова Т., Забудский Ю., Камалов Р., Ефимов И. Применение популяционно-генетических параметров в селекции молочного скота. Молочное и мясное скотоводство. 2012. № 1, С. 17-18.

7. Зубець М. В., Полупан Ю. П. Методи і значення екстер'єрної оцінки молочної худоби. Нові методи селекції і відтворення високопродуктивних порід і типів тварин: Матеріали науково-виробничої конф. К., 1996. С. 74-75.

8. Карымсаков Т. Н. Фенотипические и генетические показатели экстерьерных признаков голштинизированного молочного скота Казахстана. Ученые записки Казанской государственной академии ветеринарной медицины им. Н.Э. Баумана. 2018. T.240. №4. С. 101-104.

9. Контэ А. Ф., Ермилов А. Н., Сермягин А. А. Оценка динамики генетической изменчивости для показателей типа телосложения коров-первотелок голштинизированной черно-пестрой породы подмосковья. Вестник КрасГАУ. 2020. № 8 (161). C. 69-78.

10. Контэ А. Ф., Харитонов С. Н., Сермягин А. А., Ермилов А. Н., Янчуков И. Н., Зиновьева Н. А. Изменчивость селекционно-генетических параметров линейной оценки типа телосложения дочерей быков популяции голштинизированного черно-пестрого скота. Молочное и мясное скотоводство. 2017. №8. С.3-9.

11. Кушнер Х. Ф. Наследственность сельскохозяйственных животных. Москва: Колос, 1964. С. 224-249.

12. Ладика В. І., Хмельничий Л. М., Буркат В. П., Рубан С. Ю. Реєстрація ICAR. Довідник. Суми: Сумський національний аграрний університет, 2010. 457 с.

13. Меркурьева Е. К. Генетические основы селекции в скотоводстве. М. : Колос, 1977. 240 с.

14. Хмельничий Л. М., Ладика В. І., Полупан Ю. П., Братушка Р. В., Прийма С. В., Вечорка В. В. Лінійна класифікація корів молочних і молочно-м'ясних порід за типом. (Методичні вказівки) - 2-е вид., перероб. і доп. Суми : Сумський національний аграрний університет, 2016. 27 с.

15. Новоселова К.С. Связь молочной продуктивности коров-первотелок с экстерьером в СХПК-СХА (колхоз) "Первое Мая". Актуальные вопросы совершенствования технологии производства и переработки продукции сельского хозяйства. 2019. № 21. С.356-359. 31

16. Полупан Ю. П. Повторяемость и взаимосвязь инструментальной и глазомерной оценки экстерьера крупного рогатого скота. Сельскохозяйственная биология. 2000. № 2. С. 108-114. 42

17. Полупан Ю. П. Суб’єктивні акценти з деяких питань основ селекції та породоутворення. Розведення і генетика тварин. К.: Аграрна наука. 2007. Вип.41, С. 194-208.

18. Тимофеев-Ресовский, Н. В., Яблоков А. В., Глотов Н. В.. Очерк учения о популяции. М.: Наука, 1973. 277 с.

19. Хмельничий Л. М. Особливості екстер'єрного типу корів української чорно-рябої молочної породи Черкаського регіону оцінених за методикою лінійної класифікації. Розведення і генетика тварин. 2017. Вип. 54. С. 112-119.

20. Хмельничий Л. М. Практикум з селекції сільськогосподарських тварин. Суми: видавництво ФОП Литовченко Є.Б., 2014. $256 \mathrm{c}$.

21. Хмельничий Л. М. Успадковуваність лінійних ознак екстер'єру. Науковий вісник Львівської націон. акад. вет. медицини ім. С.3. Гжицького. Львів. 2004. Т. 6 (3). Ч. 5. С. 58-62.

22. Хмельничий Л. М. Успадковуваність та кореляційна мінливість лінійних ознак екстер'єру корів-первісток української червоно-рябої молочної породи Черкащини. Науково-інформаційний Вісник Херсонського державного аграрного університету. Херсон. 2018. Вип. 11. С. 73-75.

23. Хмельничий Л. М., Вечорка В. В. Вплив лінійних ознак екстер'єру на стан молочної продуктивності корів-первісток українських чорно-рябої та червоно-рябої молочних порід. Вісник Сумського національного аграрного університету. Серія «Тваринництво». 2020. Вип. 1(40). C.11-16. DOI: https://doi.org/10.32845/bsnau.lvst.2020.1.2

24. Хмельничий Л. М., Вечорка В.В.Життєздатність корів українських чорно-рябої та червоно-рябої молочних порід залежно від оцінки лінійних ознак екстер'єру. Вісник Сумського національного аграрного університету. Серія «Тваринництво». 2017. Вип. 7 (33). С. 48-58.

25. Хмельничий Л. М., Вечорка В. В., Хмельничий С. Л. Тривалість життя корів української бурої молочної породи в залежності від лінійної оцінки морфологічних ознак вимені. Технологія виробництва і переробки продукції тваринництва. Збірник наукових праць Білоцерківського ДАУ. 2020. Вип. 1(156). С. 29-37.

26. Хмельничий Л. М., Салогуб А. М., Хмельничий С. Л., Лобода А. В. Співвідносна мінливість та успадковуваність лінійних ознак екстер'єру корів сумського внутрішньопородного типу української чорно-рябої молочної породи. Вісник Сумського національного аграрного університету. Серія «Тваринництво». 2018. Вип. 2 (34). С. 92-96.

27. Хмельничий Л. М., Супрун І. О. Основи генетики та селекції сільськогосподарських тварин. К.: Аграрна освіта, 2011. 497 c.

28. Almeida T.P., Kern E.L., Daltro D. dos S., Neto, J. B., McManus C., Neto A.T., and Cobuci J.A. 2017. Genetic associations between reproductive and linear-type traits of Holstein cows in Brazil. R. Bras. Zootec., 46(2):91-98.

29. Alphonsus, C., Akpa G.N., Oni O.O., Rekwot P.I., Barje P.P., and Yashim S.M., 2010. Relationship of Linear Conformation Traits with Bodyweight, Body Condition Score and Milk yield in Friesian × Bunaji Cows, Journal of Applied Animal Research, 38(1): 97-100. https://doi.org/10.1080/09712119.2010.9707164

30. De Haas Y,. Janss L. L. G., Kadarmideen H. N. Genetic and phenotypic parameters for conformation and yield traits in three Swiss dairy cattle breeds. J. Anim. Breed. Genet. 2007. 124(1), pp. 12-19. DOI:10.1111/j.1439-0388.2007.00630.x

31. Du Toit, J., Van Wyk J.B. and Maiwashe A., 2012. Relationships between functional herd life and conformation traits in the South African Jersey breed. South African Journal of Animal Science 2012, 42 (No. 1).p. 47-54. DOI: 10.4314 / sajas.v42i1.6 
32. Duru S., Kumlu, S., Tuncel, E. Estimation of variance components and genetic parameters for type traits and milk yield in Holstein cattle. Turkish Journal of Veterinary \& Animal Sciences 2012; 36(6): 585-591. doi: 10.3906/vet-1012-660.

33. Efimova L. V., Rostovtseva N. M., Kulakova T. V., Ivanova O. V., Ivanov E. A. Russian Journal of Agricultural and Biological Sciences., 2017. Vol. 5, No. 2, pp. 4-15.

34. Jovanovac, S., and N. Raguž. 2011. Analysis of the relationships between type traits and longevity in Croatian Simmental cattle using survival analysis. Agriculturae Conspectus Scientificus. 76(30): 249[253. doi: https://hrcak.srce.hr/7204610

35. Kern E. L., Cobuci J. A., Costa C. N., McManus C. M., Campos G. S., Almeida T. P., Campos R. V. Genetic association between herd survival and linear type traits in Holstein cows under tropical conditions. Italian J. Animal Science. 2014. 13:3419.

36. Makgahlela, M.L., Mostert B.E. and Banga C.B., 2009. Genetic relationships between calving interval and linear type traits in South African Holstein and Jersey cattle. South African Journal of Animal Science 2009, 39 (Supplement 1). P.90-92.

37. Novotný L., Frelich J., Beran J., Zavadilová L. Genetic relationship between type traits, number of lactations initiated, and lifetime milk performance in Czech Fleckvieh cattle. Czech J. Anim. Sci., 2017. 62:501-510.

38. Sabedot M.A., Romano G. de S., Pedrosa V.B., Pinto L.F.B. Genetic parameters for type score traits and milk production in Brazilian Jersey herds. R. Bras. Zootec., 2018. 47:e20170093. https://doi.org/10.1590/rbz4720170093

39. Sawa, A., Bogucki M., Krwhel-Czopek S., and Neja W., 2013. Relationship between conformation traits and lifetime production efficiency of cows. Life Sciences. 85-084. https://doi.org/10.1155/2013/124690

40. Špehar, M., Štepec M., Potočnik K. Variance components estimation for type traits in Slovenian Brown Swiss cattle. Acta argiculturae Slovenica. 2012. 100(2): 107-115.

41. Tapki, I. and Ziya G.Y., 2013. Genetic and phenotypic correlations between linear type traits and milk production yields of Turkish Holstein dairy cows. Green. J. Agric. Sci. 3(11): 755-761.

42. Wiggans, G. R., Thornton, L. L. M, Neitzel, R. R., Gengler N. J., Genetic Parameters and Evaluation of Rear Legs (Rear View) for Brown Swiss and Guernseys. Dairy Sci. 2006. 89:4895-4900.

43. Zink, V., L. Zavadilová, J. Lassen, M. Štípková, M. Vacek, L. Štolc. 2014. Analyses of genetic relationships between linear type traits, fat-to-protein ratio, milk production traits, and somatic cell count in first-parity Czech Holstein cows. Czech J. Anim. Sci., 59(12): 539-547.

44. Інструкція з бонітування великої рогатої худоби молочних і молочно-м'ясних порід. Наказ Міністерства аграрної політики та продовольства № 50 (z0380-17 ) від 10.02.2017. [Електроний ресурс]. - Режим доступу : https://zakon.rada.gov.ua/laws/show/z0095-04\#Text

\section{References:}

1. Adushinov, D., Lazarev, N., Istomin, A. and Mitrenga, V., 2011. Tip teloslozheniya i khozyaystvenno-poleznye priznaki golshtinizirovannogo cherno-pestrogo skota [Body type and economically useful traits of Holsteinized Black-and-White cattle]. Molochnoe i myasnoe skotovodstvo, no 5, pp. 16-17.

2. Basovskiy, N. Z., 1983. Populyatsionnaya genetika v selektsii molochnogo skota [Population genetics in selective breeding of dairy cattle]. Moskva: Kolos.

3. Burkat, V. P., Yefimenko, M. Ya., Podoba, B. Ye. and Dzitsiuk, V. V., 2003. Naukovi i prykladni aspekty henetychnoho monitorynhu u tvarynnytstvi [Scientific and applied aspects of genetic monitoring in animal husbandry]. Visnyk ahrarnoi nauky, no. 5, pp. 32-39.

4. Burkat, V. P., Polupan, Iu. P. and Yovenko, I. V., 2004. Liniina otsinka koriv za typom [Linear estimation of cows by type]. Kyiv: Ahrarna nauka.

5. Yu. F. Melnyk, V. P. Kovalenko and A. M. Unnivenko. eds., 2008. Hopka, B. M., Kovalenko, V. P., Melnyk, Yu. F., Kovalenko, V. P., Uhnivenko, A. M. et al. Selektsiia silskohospodarskykh tvaryn [Breeding of farm animals]. Kyiv: «Intas».

6. Delyan, A., Shcheglov, E., Usova, T., Zabudskiy, Yu., Kamalov, R., and Efimov, I., 2012. Primenenie populyatsionno-geneticheskikh parametrov v selektsii molochnogo skota [Use of population genetic parameters in breeding dairy cattle]. Molochnoe i myasnoe skotovodstvo, no. 1, pp. 17-18.

7. Zubets, M. V. and Polupan, Yu. P., 1996. Metody i znachennia eksteriernoi otsinky molochnoi khudoby [Methods and significance exterior estimation of dairy cattle]. New methods of selection and reproduction of highly productive breeds and types of animals, Proceedings of the International Conference, 1996. Kyiv, pp. 74-75.

8. Karymsakov, T. N., 2018. Fenotipicheskie i geneticheskie pokazateli ekster'ernykh priznakov golshtinizirovannogo molochnogo skota Kazakhstana [Phenotypic and genetic indicators of the conformation traits of Holsteinized dairy cattle in Kazakhstan]. Uchenye zapiski Kazanskoy gosudarstvennoy akademii veterinarnoy meditsiny im. N.E. Baumana. vol. 240, no 4, pp. 101-104.

9. Konte, A. F., Ermilov, A. N. and Sermyagin, A. A., 2020. Otsenka dinamiki geneticheskoy izmenchivosti dlya pokazateley tipa teloslozheniya korov-pervotelok golshtinizirovannoy cherno-pestroy porody podmoskov'ya [Assessment of the dynamics of genetic variability for indicators of body type cows, heifers Holsteinized Black-and-White breed in the Moscow region]. Vestnik Krasnoyarskogo GAU, no. 8(161), pp. 69-78.

10. Konte, A. F., Kharitonov, S. N., Sermyagin A. A., Ermilov, A. N., Yanchukov, I. N. and Zinov'eva, N. A., 2017. Izmenchivost' selektsionno-geneticheskikh parametrov lineynoy otsenki tipa teloslozheniya docherey bykov populyatsii golshtinizirovannogo chernopestrogo skota [Variability of selection and genetic parameters of the body type linear assessment of daughters of bulls in the population of Holsteinized Black-and-White cattle]. Molochnoe i myasnoe skotovodstvo, no. 8, pp. 3-9.

11. Kushner, Kh. F., 1964. Nasledstvennost' sel'skokhozyaystvennykh zhivotnykh [The heredity of farm animals]. Moskva: Kolos.

12. Ladyka, V. I., Khmelnychyi, L. M., Burkat, V. P. and Ruban, S. Yu. 2010. Reyestratsiya ICAR. Dovidnyk [ICAR Registration: 
Reference book]. Sumy: Sumy National Agrarian University.

13. Merkur'eva, E. K., 1977. Geneticheskie osnovy selektsii v skotovodstve [Genetic bases of selection in livestock]. Moskva: Kolos.

14. Khmelnychyi, L. M., Ladyka, V. I., Polupan, Yu. P., Bratushka, R. V., Pryima, S. V. and Vechorka, V. V., 2016. Liniina klasyfikatsiia koriv molochnykh i molochno-miasnykh porid za typom. (Metodychni vkazivky) - 2-e vyd., pererob. i dop. [Linear classification of dairy and dairy-meat cows by type. (Methodical instructions). 2nd ed., reworked and ext.]. Sumy: Sumskyi natsionalnyi ahrarnyi universytet.

15. Novoselova, K. S., 2019. Svyaz' molochnoy produktivnosti korov-pervotelok s ekster'erom v SKhPK-SKhA (kolkhoz) "Pervoe Maya" [The connection between milk productivity of first-calf cows with conformation in the SKHPK-SHA (collective farm) "Pervoe Maya"]. Aktual'nye voprosy sovershenstvovaniya tekhnologi proizvodstva i pererabotki produktsii sel'skogo khozyaystva, no. 21, pp. 356-359.

16. Polupan, Yu. P., 2000. Povtoryaemost' i vzaimosvyaz' instrumental'noy i glazomernoy otsenki ekster'era krupnogo rogatogo skota [Repeatability and interrelation of instrumental and visual assessment of the cattle conformation]. Sel'skokhozyaystvennaya biologiya, no. 2, pp. 108-114.

17. Polupan, Yu. P., 2007. Subiektyvni aktsenty z deiakykh pytan osnov selektsii ta porodoutvorennia [Subjective accents on some questions about genetic basis of selection and breed formation]. Rozvedennia i henetyka tvaryn, issue 41, pp. $194-208$.

18. Timofeev-Resovskiy, N.V., Yablokov, A.V. and Glotov, N.V., 1973. Ocherk ucheniya o populyatsii [Essay on the doctrine about the population]. Moskva: Nauka.

19. Khmelnychyi, L. M., 2017. Osoblyvosti eksteriernoho typu koriv ukrainskoi chorno-riaboi molochnoi porody Cherkaskoho rehionu otsinenykh za metodykoiu liniinoi klasyfikatsii [Conformation type features of cows Ukrainian Black-and-White dairy breed in Cherkassy region estimated by the method of linear classification]. Rozvedennia i henetyka tvaryn, issue 54, pp. 112-119.

20. Khmelnychyi, L. M., 2014. Praktykum z selektsii silskohospodarskykh tvaryn [Workshop on breeding of farm animals]. Sumy: Vydavnytstvo: FOP Lytovchenko, Ye. B.

21. Khmelnychyi, L. M., 2004. Uspadkovuvanist liniinykh oznak eksterieru [Heritability of the linear conformation traits]. Naukovyi visnyk Lvivskoi natsion. akad. vet. medytsyny im. S. Z. Hzhytskoho, vol. 6(3), pp. 58-62.

22. Khmelnychyi, L. M., 2018. Uspadkovuvanist ta koreliatsiina minlyvist liniinykh oznak eksterieru koriv-pervistok ukrainskoi chervono-riaboi molochnoi porody Cherkashchyny [Heritability and correlation variability of linear conformation traits cows firstborn Ukrainian Red-and-White dairy breed of Cherkasy region]. Naukovo-informatsiinyi Visnyk Khersonskoho derzhavnoho ahrarnoho universytetu. Kherson, issue 11, pp. 73-75.

23. Khmelnychyi, L. M. and Vechorka, V. V., 2020. Influence of linear conformation traits on the state of milk productivity cows firstborn of Ukrainian Black- and Red-and-White dairy breeds [Vplyv liniinykh oznak eksterieru na stan molochnoi produktyvnosti korivpervistok ukrainskykh chorno-riaboi ta chervono-riaboi molochnykh porid]. Visnyk Sumskoho natsionalnoho ahrarnoho universytetu. Seriia «Tvarynnytstvo», issue 1(40), pp. 11-16. doi: https://doi.org/10.32845/bsnau.lvst.2020.1.2

24. Khmelnychyi, L. M. and Vechorka, V. V., 2017. Zhyttiezdatnist koriv ukrainskykh chorno-riaboi ta chervono-riaboi molochnykh porid zalezhno vid otsinky liniinykh oznak eksterieru [Viability cows Ukrainian Black-and Red-and-White dairy breeds depending on the assessment of linear conformation traits]. Visnyk Sumskoho natsionalnoho ahrarnoho universytetu. Seriia «Tvarynnytstvo», issue 7(33), pp. 48-58.

25. Khmelnychyi, L. M., Vechorka, V. V. and Khmelnychyi, S. L., 2020. Tryvalist zhyttia koriv ukrainskoi buroi molochnoi porody v zalezhnosti vid liniinoi otsinky morfolohichnykh oznak vymeni [Lifetime of Ukrainian Brown dairy cows depending on the linear assessment of udder morphological traits]. Tekhnolohiia vyrobnytstva i pererobky produktsii tvarynnytstva. Zbirnyk naukovykh prats Bilotserkivskoho DAU, issue 1(156), pp. 29-37.

26. Khmelnychyi, L. M., Salohub, A. M., Khmelnychyi, S. L. and Loboda, A. V., 2018. Spivvidnosna minlyvist ta uspadkovuvanist liniinykh oznak eksterieru koriv sumskoho vnutrishnoporodnoho typu ukrainskoi chorno-riaboi molochnoi porody [Correlative variability and heritability of conformation linear traits cows of Sumy intrabreed type of Ukrainian Black-and-White dairy breed]. Visnyk Sumskoho natsionalnoho ahrarnoho universytetu. Seriia «Tvarynnytstvo», issue 2(34), 92-96.

27. Khmelnychyi, L. M. and Suprun, I. O., 2011. Osnovy henetyky ta selektsii silskohospodarskykh тварин [Fundamentals of genetics and selection of farm animals]. Kyiv: Ahrarna osvita.

28. Almeida, T. P., Kern, E. L., Daltro, D. dos S., Neto, J. B., McManus, C., Neto, A. T. and Cobuci, J. A., 2017. Genetic associations between reproductive and linear-type traits of Holstein cows in Brazil. R. Bras. Zootec., 46(2):91-98.

29. Alphonsus, C., Akpa, G. N., Oni, O. O., Rekwot, P. I., Barje, P. P. and Yashim, S. M., 2010. Relationship of linear conformation traits with body weight, body condition score and milk yield in Friesian $\times$ Bunaji Cows, Journal of Applied Animal Research, 38(1): 97-100. https://doi.org/10.1080/09712119.2010.9707164

30. De Haas, Y,. Janss, L. L. G. and Kadarmideen, H. N., 2007. Genetic and phenotypic parameters for conformation and yield traits in three Swiss dairy cattle breeds. J. Anim. Breed. Genet. 124(1): 12-19. DOI:10.1111/j.1439-0388.2007.00630.x

31. Du Toit, J., Van Wyk, J. B. and Maiwashe, A., 2012. Relationships between functional herd life and conformation traits in the South African Jersey breed. South African Journal of Animal Science, 42(1): 47-54. DOI: 10.4314 / sajas.v42i1.6

32. Duru, S., Kumlu, S. and Tuncel, E., 2012. Estimation of variance components and genetic parameters for type traits and milk yield in Holstein cattle. Turkish Journal of Veterinary\&Animal Sciences; 36(6): 585-591. doi: 10.3906/vet-1012-660.

33. Efimova, L. V., Rostovtseva, N. M., Kulakova, T. V., Ivanova, O. V., and Ivanov, E. A., 2017. Russian Journal of Agricultura and Biological Sciences., Vol. 5, (2): 4-15.

34. Jovanovac, S. and Raguž, N., 2011. Analysis of the relationships between type traits and longevity in Croatian Simmental 
cattle using survival analysis. Agriculturae Conspectus Scientificus. 76(30): 249-253. doi: https://hrcak.srce.hr/7204610

35. Kern, E. L., Cobuci, J. A., Costa, C. N., McManus, C. M., Campos, G. S., Almeida, T. P. and Campos, R. V., 2014. Genetic association between herd survival and linear type traits in Holstein cows under tropical conditions. Italian J. Animal Science. 13:3419.

36. Makgahlela, M. L., Mostert, B. E. and Banga, C. B., 2009. Genetic relationships between calving interval and linear type traits in South African Holstein and Jersey cattle. South African Journal of Animal Science, 39 (Supplement 1):90-92.

37. Novotný, L., Frelich, J., Beran, J. and Zavadilová, L., 2017. Genetic relationship between type traits, number of lactations initiated, and lifetime milk performance in Czech Fleckvieh cattle. Czech J. Anim. Sci., 62:501-510.

38. Sabedot, M. A., Romano, G. de S., Pedrosa, V. B. and Pinto, L. F. B., 2018. Genetic parameters for type score traits and milk production in Brazilian Jersey herds. R. Bras. Zootec., 47:e20170093. https://doi.org/10.1590/rbz4720170093

39. Sawa, A., Bogucki, M., Krwhel-Czopek, S. and Neja W., 2013. Relationship between conformation traits and lifetime production efficiency of cows. Life Sciences. 85-084. https://doi.org/10.1155/2013/124690

40. Špehar, M., Štepec, M. and Potočnik, K., 2012. Variance components estimation for type traits in Slovenian Brown Swiss cattle. Acta argiculturae Slovenica. 100(2): 107-115.

41. Tapki, I. and Ziya, G. Y., 2013. Genetic and phenotypic correlations between linear type traits and milk production yields of Turkish Holstein dairy cows. Green. J. Agric. Sci. 3(11): 755-761.

42. Wiggans, G. R., Thornton, L. L. M, Neitzel, R. R. and Gengler, N. J., 2006. Genetic parameters and evaluation of rear legs (rear view) for Brown Swiss and Guernseys. Dairy Sci. 89:4895-4900.

43. Zink, V., L., Zavadilová, J., Lassen, M., Štípková, M. and Vacek, L. Štolc., 2014. Analyses of genetic relationships between linear type traits, fat-to-protein ratio, milk production traits, and somatic cell count in first-parity Czech Holstein cows. Czech J. Anim. Sci., 59(12): 539-547.

44. Instruktsiia z bonituvannia velykoi rohatoi khudoby molochnykh i molochno-miasnykh porid. Nakaz Ministerstva ahrarnoi polityky ta prodovolstva № 50 (z0380-17) vid 10.02.2017 [Instructions for grading cattle of dairy and dairy-meat breeds. By order of the Ministry of Agrarian Policy and Food № 50 (z0380-17) dated 10.02.2017]. [Electronic resource]. - Access mode : https://zakon.rada.gov.ua/laws/show/z0095-04\#Text

Karpenko Bogdan Mykolaiovych, PhD student, Sumy National Agrarian University (Sumy, Ukraine)

Heritability and correlated variability with milk yield of linear traits firstborn cows of Holstein breed

Studies were conducted to estimate the first-born cows of Holstein breed (Ukrainian Black-and-White dairy with a conditional bloodline of Holstein above 93.75\%) by conformation type. The research base was the breeding farm of PE "Buryns'ke" of Pidlisnivskyi branch in Sumy district. A modern method of linear classification was used with an assessment by two systems: 9-score, describing 18 body parts of the conformation, and 100-score, taking into account four complexes of selection type traits that characterize: dairy type, body, limbs and udder. The population-genetic aspect was described by determining the heritability and correlative variability of linear traits with milk yield of Holstein cows of domestic breeding in Sumy region. Group traits that characterize the dairy type of cows $(r=0.398)$, body development $(r=0.412)$, limb condition $(r=0.215)$, udder morphological qualities $(r=0.466)$ and final type assessment were best correlated with milk yield $(r=0.474)$. The highest coefficients of heritability were found for group traits of dairy type $\left(h^{2}=\right.$ $0.366)$, body $\left(h^{2}=0.328\right)$, udder $\left(h^{2}=0.385\right)$ and final score $\left(h^{2}=0.477\right)$. The average and moderate level of heritability was determined by descriptive traits: height $\left(h^{2}=0.286\right)$, body depth $\left(h^{2}=0.275\right)$, angularity $\left(h^{2}=0.414\right)$, rear width $\left(h^{2}=0.295\right)$, pelvic limbs posture $\left(h^{2}=0.274\right)$, fore $\left(h^{2}=0.351\right)$ and rear $\left(h^{2}=0.296\right)$ udder attachment and central ligament $\left(h^{2}=0.294\right)$. A sufficient level heritability of linear traits and correlative variability between them and milk yield allowed breeders to effectively select dairy cattle in the direction of improving the conformation and productivity.

Key words: Holstein breed, conformation, milk yield, correlation, heritability

Дата надходження до редакції: 21. 10.2020 р. 